\title{
Литовская Католическая академия наук: деятельность медиков
}

\author{
Алдона Василяускене
}

Празднование тысячелетия Литвы дает прекрасную возможность и стимулирует литовских ученых, в первую очередь историков, предоставить широкой общественности как можно больше сведений о своей стране и о личностях, творивших, укреплявших и популяризировавших государство, его учреждения и организации. Одна из малоизвестных общественных организаций ученым других стран - Литовская католическая Академия наук (ЛКАН). Созданная в 1922 году, она много сделала для укрепления независимого Литовского государства, а после его оккупации, будучи в эмиграции, немало совершила для популяризации ее имени в борьбе за свободу.

В настоящей работе представлена деятельность медиков в Литовской католической Академии наук, а также дан обзор истории Католической академии, ее структура, направления деятельности, в особенности деятельность секции медиков. В исследовании использованы архивные материалы, печатные архивные источники, научные труды, посвященные изучению истории ЛКАН, публицистика.

\section{Из ИсторИИ ЛКАН}

В Европе в настоящее время известны Католические академии и Католические академии наук. Первые организуют разного рода мероприятия (лекции, дискуссии, диспуты), в которых широко популяризируется наука, занимающаяся научно-исследовательской работой.

Литовская католическая Академия наук (ЛКАН) [1] - это соединение двух вышеупомянутых типов, имеющее две цели: организацию научной работы и популяризацию науки. Эти цели отражены и в Уставе ЛКАН.

ЛКАН объединяет литовских ученых католического мировоззрения всех областей науки, живущих не только в Литве, но и за рубежом, стремящихся 


\section{А. Василяускене}

к единству научной и христианской мысли и творчества, чтобы общими усилиями всех литовцев достичь научного и духовного прогресса.

В истории ЛКАН, переступившей в 2007 г. порог своего 85-летия, выделяются три периода деятельности: создание ЛКАН и ее деятельность в независимой Литве (1922-1940); восстановление и деятельность ЛКАН в эмиграции, в Риме (1956-1992); деятельность ЛКАН после восстановления Академии в Литве - с 1990 г., а с 1992 г. после переноса центрального правления Литовской католической Академии наук (см. схему № 1, стр. 192).

Идея создания ЛКАН и ее осуществление. Идея создания ЛКАН возникла еще в 1908 г.: в Каунасе, в издаваемом прелатом Александрасом Дамбраускасом (Адомасом Якштой, 1860-1938) издании "Драугия" ("Общество") была опубликована статья Пранцишкуса Пятраса Бучиса МIC (1872-1951) "Международное католическое объединение для возвышения науки и Литва". Эта статья - отзыв на энциклику Папы Римского Пия X "Pascendi domini Gregis" (1907), осуждающую ошибки модернизма. В энциклике была упомянута и организация, которая должна была-бы объединить ученых прогрессивно работающих в области культуры и науки.

П. Бучис говорил не только о необходимости создания научной организации в Литве, выдвигая идею объединения ученых-католиков, но и о возможности ее укрепления и расцвета при включении в международные организации. Другим идеологом ЛКАН был А. Дамбраускас. Однако из-за разногласий с действовавшим в Вильнюсе "Научным обществом" Академия в то время не была создана.

Устав ЛКАН был утвержден и зарегистрирован в Каунасских городских и областных учреждениях 12 сентября 1922 г., а Акт об учреждении принят 22 октября того же года. Во время учредительного собрания было выбрано правление. Первым председателем (1922-1926) ЛКАН был избран епископ Юозапас Сквиряцкас (1873-1959), затем председательствовал (1926-1938) А. Дамбраускас, а с 1938 года по 1940 год - Стасис Шалкаускис (1886-1941) (см. схему № 2, стр. 192). В 1940 году ЛКАН, как и другие католические организации и учреждения, была закрыта советскими оккупантами. Она не возобновила своей деятельности и во время немецкой оккупации.

Второй период деятельности ЛКАН. Мысль о восстановлении деятельности ЛКАН в эмиграции первым высказал тогдашний представитель Литвы в Париже др. Стасис Антанас Бачкис (1906-1999), который последовательно призывал к ее осуществлению. Летом 1952 года он разослал жившим в эмиграции литовским епископам и ученым-мирянам письма с предложением восстановить деятельность Католической академии и призывал взять инициативу по ее восстановлению в Риме, где уже была создана Литовская коллегия Св. Казимира. По просьбе епископа Винцента Падольскиса (1904-1960) Бачкис выслал ему копию устава ЛКАН. 
30 декабря 1954 г. в Риме для восстановления ЛКАН была создана Реорганизационная комиссия. В качестве гарантов непрерывности деятельности Академии в состав Реорганизационной комиссии были предложены члены Центрального правления ЛКАН 1940 г. проф. Зенонас Ивинскис (19081971) и швейцарец проф. Юозас Эретас (Joseph Ehret, 1896-1984), живший в 1919-1941 гг. в Литве, принявший литовское гражданство и всю оставшуюся жизнь популяризировавший Литву.

Акт о восстановлении Академии был подписан (об этом было объявлено в печати), а 9 октября 1956 г. в полиции Италии был зарегистрирован переведенный на итальянский язык и приспособленный к существующим условиям Устав ЛКАН. Центром Академии в эмиграции стал Рим, где он и действовал до возвращения в Литву в 1992 году.

Во второй период ЛКАН - в 1956-1959 гг. - Академией руководил епископ Винцентас Падольскис, а в 1959-1992 гг. - проф. ксендз Антанас Люйма S. J. (1920-2000). Когда в 1992 г. Центр ЛКАН был перенесен в Литву, А. Люйма был избран первым Почетным председателем ЛКАН (см. схему № 2, стр. 192).

Восстановление ЛКАН в Литве. С 1989 г. в связи с изменением политической ситуации в Литве началось восстановление деятельности различных обществ и организаций, уничтоженных или разогнанных в годы первой или второй советской оккупации. 26 ноября 1989 г. на восстановительном съезде Федерации атейнинкасов была выдвинута мысль о восстановлении ЛКАН в Литве. 17 февраля 1990 г. была созвана Учредительная конференция ЛКАН. Для руководства Академией был избран Литовский Краевой совет в составе 10 человек, который сформировал Правление из 4 человек. Председателем Правления был избран широко известный в Литве кардиохирург проф. Гедрюс Уждавинис - первый и единственный медик, возглавлявший ЛКАН.

8 мая 1990 г. ЛКАН была зарегистрирована в Совете министров Литвы, а 9 мая Центральное правление в Риме поддержало и одобрило Литовский Краевой совет и его Правление.

До 2007 года Устав ЛКАН, утвержденный в 1999 и в 2001 гг., несколько раз дополнялся. Во время второго дополнения был предусмотрен шестилетний, а не трехлетний период деятельности избранного Центрального правления и Ревизионной комиссии. Литовская Католическая академия наук была утверждена как общественная организация.

Председатели восстановленной в Литве ЛКАН: в 1992-1997 гг. проф. Стасис Уждавинис, в 1997-2006 гг. др. епископ Йонас Борута S. J., а с 2006 г. др. Паулюс Субачюс (см. схему № 2, стр. 192).

Структура ЛКАН. Деятельностью ЛКАН руководит избираемое всеми членами ЛКАН Центральное правление. Члены Центрального правления распределяют между собой обязанности председателя, заместителей председателя (по науке, культуре, издательской деятельности, финансам), ученых 


\section{А. Василяускене}

секретарей, в эмиграции были также книговеды-архивариусы. Кроме того, избирается ревизионная комиссия в составе трех человек.

В структуру ЛКАН входят более крупные подразделения - отделения, и более мелкие - секции.

В эмиграции у ЛКАН было несколько подразделений. Одно из них Центр документальных материалов о положении религии в Литве (архив), где собирались важные сведения и данные для ознакомления с положением религии в оккупированной Литве. Все годы собирался материал для подготовки информационных бюллетеней, однако в феврале 1964 г. Религиозный фонд прекратил финансовую помощь, и ЛКАН не смогла до конца реализовать начатую работу.

14 июня 1965 г. ЛКАН создало в Риме еще одно важное учреждение - в Риме Литовский Институт истории и религиозной культуры ЛКАН, сокращенно называвшимся Литовский Институт. Инициаторы этой идеи - члены ЛКАН монсеньор Клеменсас Разминас, др. ксендз Паулюс Ятулис и ксендз Раполас Красаускас.

В 1973 г. Академия пополнилась уже третьим учреждением - прелат Пранцишкус Юрас передал Академии им лично собранный и особо ценный культурный Архив американских литовцев ((Алка). Обосновавшийся в Путнаме Архив состоял из 4 внушительных подразделов: богатой Литуанистической библиотеки, Собрания архивно-рукописных и документальных материалов, Музея этнографии и народного творчества и Художественной галереи.

В 1974 г. в Литовский Институт истории и религиозной культуры была включена серия книг "Krikščionis gyvenime" ("Христианин в жизни"), издаваемая Витаутасом Бальчюнасом в США. Влившись в институт, действующий в соответствии со своим уставом и названными направлениями Krikščionis gyvenime укреплял общие силы, обеспечивая более продуктивный результат работы.

Отделения. В первый период деятельности Католической академии отделения не были созданы (территория Литвы небольшая, кроме того значительная ее часть была оккупирована Польшей).

В конце Второй мировой войны с приближением советского фронта большая часть литовцев, стремясь избежать столкновений, перебралась на Запад и рассеялась по всему миру.

В эмиграции, там, где возникли более крупные литовские поселения, учреждались отделения ЛКАН. Создание отделений преследовало несколько целей: создать условия для того, чтобы как можно больше литовцев могло включиться в научную деятельность и чтобы их не ограничивали большие расстояния и финансовые расходы. Занимаясь научной работой, они знакомили население территорий, принадлежащих разным национальностям, с достижениями литовцев в области науки - так пробуждался и укреплялся интерес к литовскому народу и к Литве. Кроме того, проводимая отделе- 
ниями ЛКАН работа дополняла деятельность Католической академии по информированию мира о положении порабощенной Литвы, способствовала борьбе за свободу, пробуждению надежды и веры в будущую), Торонто (09.12.1964), Дейтоне (24.01.1965), Мюнхене (20.02.1966), Оттаве (май 1970), Путнаме (декабрь 1971), Сент-независимую Литву.

За 36 лет деятельности в эмиграции было создано 12 таких отделений: в Чикаго (17.10.1956), Нью-Йорке (15.12.1962), Бостоне (17.11.1963), Детройте (09.02.1964), Монреале (22.05.1964), Питерсбурге-Бич (17.10.1981), ЛосАнжелесе (июль 1983). Выше уже упомянутый Литовский Краевой совет, который вначале подчинялся Центральному правлению ЛКАН в Риме. Все отделения работали как действующая на местах организация с Центральным правлением, находящимся в Риме.

После восстановления Католической академии в Литве количество ее членов быстро росло, поэтому здесь также возникали отделения: в Вильнюсе (17.02.1990), в Клайпеде (17.04.1991), Каунасе (31.01.1992), Паневежисе (08.02.1992), Шяуляй (01.07.1992), Аникшчяй (24.11.1992), Алитусе (22.05.1994), Утяне (28.05.1994), Тяльшяй (24.09.1996). Однако можно сожалеть, что деятельность некоторых отделений после смерти их руководителей прервалась. Особое положение было в Вильнюсском отделении, которым долгое время руководило правление Литовского Краевого совета, позднее довольно длительное время - Центральное правление ЛКАН, пока первым руководителем Вильнюсского отделения не был назначен проф. Напалис Киткаускас.

Секции. Самое мелкое подразделение ЛКАН - секции. Научная работа съездов - доклады и дискуссии - проходила в соответствующих тематических секциях. Здесь получила начало и дальнейшая научная группировка по постоянным предметным секциям.

В 1933 г. во время первого съезда ЛКАН были сформированы первые четыри секции: теологическая, философско-педагогическая, лингвистическая и социологическая.

В 1936 г. на втором съезде были созданы новые (историческая, объединенная медицинско-теологическая, юридическая и женская) секции, другие же расширили рамки своей деятельности: лингвистическая секция получила название "Секция языка, литературы и искусства", а социологическая - "Секция социальных и экономических наук".

На третьем съезде (1939) действовало восемь секций. Были созданы новые секции: педагогическая и естественнонаучная, бывшая философскопедагогическая секция стала психологическо-философской, свою деятельность завершила женская секция.

В эмиграции постоянно действовала только одна секция - историческая, созданная в Риме в 1960 г. Другие секции формировались во время каждого съезда. 
После восстановления Академии в Литве, в Вильнюсском и Каунасском отделениях начали действовать секции. В Вильнюсском отделении было создано шесть секций: социологическая (25.10.1991), педагогическая (26.10.1991), историческая (11.01.1992), медицинская (25.01.1992), этнологическая (12.12.1994), научные секции, а также группа по изучению истории церкви (26.05.1993). В Каунасском отделении действовали две научные секции: по информатике (июнь 1991) и по медицине (26.06.1991). К сожалению большинство из них по разным причинам прекратили свою деятельность или же она значительно сократилась.

Члены ЛКАН. 20 декабря 1979 г. ЛКАН объединяла 248 членов (за 19591979 гг. умерло 65), в 1984 г. - 263. 1 сентября 1998 г. в эмиграции было 176 членов ЛКАН, в Литве - 560 .

Участники ЛКАН относятся к разным уровням: 1) члены, 2) членыпомощники, 3) академики, 4) почетные члены являются ученые с ученой степенью (большинство!). Лица, окончившие высшую школу, стремящиеся к получению ученой степени или другим образом повышающие образование, принимаются как члены-помощники. Некоторым ученым за заслуги может быть присвоено звание академика. За материальную или другую весомую помощь, за заслуги в деле популяризации Литвы может присуждаться звание почетного члена ЛКАН. За 1922-2006 гг. истории деятельности ЛКАН званием академика были удостоены 53 ученых (в довоенной Литве - 10, в эмиграции - 23, после восстановления Академии в Литве - 20), почетными членами ЛКАН стали восемь человек (в довоенной Литве один, в эмиграции - пять, в третий период - два). Два человека удостоены званием дважды: звание академика ЛКАН и почетного члена ЛКАН - прел. Александрас Дамбраускас (Адомас Якштас) и проф. Юозасу Эретасу. В числе 53 академиков кардиохирург проф. Гедрюс Уждавинис (1991).

Направления деятельности ЛКАН. Направления деятельности ЛКАН: научная, издательская, организационная (см. схему № 1, стр. 192), просветительская - тесно связаны между собой и дополняют друг друга.

Важная забота Академии - создание библиотеки. Хотя это направление усложнялось отсутствием средств и помещений, книги комплектовались за счет спонсоров, а также покупались.

В эмиграции были спонсоры, которые поддерживали выпуск книг и организацию съездов ЛКАН, присуждали стипендии и премии за научную и общественную, а также журналистскую деятельность. На средства др. прелата Юозаса Прунскиса (Чикаго) в 1972 г. были вручены первые премии ЛКАН за научную и журналистскую деятельность.

Результаты научной деятельности. Научная деятельность ЛКАН проявлялась прежде всего в докладах на организованных ЛКАН и другими организациями семинарах, конференциях, симпозиумах, съездах. 
Отделения и секции оказывают помощь Центральному правлению в организации съездов. ЛКАН организовала 20 съездов. В первый период все съезды проходили в Каунасе: в 1933, 1936, 1939; одиннадцать съездов было проведено в эмиграции: 1957 (Рим), 1961 (Чикаго), 1964 (Нью-Йорк), 1967 (Хюттенфельд), 1970 (Торонто), 1973 (Бостон), 1976 (Саутфилд, пригород Детройта), 1979 (Чикаго), 1982 (Сент-Питерсбург-Бич, Флорида), 1985 (Лос Анжелес), 1988 (Рим). Шесть съездов прошло после восстановления Академии в Литве: 1991 (Вильнюс), 1994 (Каунас), 1997 (Вильнюс), 2000 (Клайпеда), 2003 (Шяуляй) и 2006 (Вильнюс).

Важное проявление научной работы ЛКАН - опубликованные труды. До конца 2001 г. издана 61 книга. В 2002 г. вышла библиография трудов ЛКАН (всего семь серий): "Труды съездов ЛКАН", "Летописи ЛКАН", "Fontes historiae Lituaniae" ("Источники по истории Литвы"), "Избранные сочинения", "Негасимые огни", "Другие издания". Кроме того, необходимо отметить также издания трех отделений ЛКАН (Клайпедского, Паневежского и Шяуляйского).

Члены Католической академии участвовали в решении и претворении в жизнь таких важных внутригосударственных вопросов, как учреждение Литовской церковной провинции и принадлежность Вильнюсского архиепископата (Юозапас Сквиряцкас, Юргис Матулайтис, Мечисловас Рейнис, Аудрис Юозас Бачкис и др.) - это вытекало из внутригосударственных вопросов. Они участвовали и в создании Литовского государства (это сигнатары Акта 16 февраля: Пранас Довидайтис, Юстинас Стаугайтис, Стяпонас Кайрис), и в укреплении государственности - занимали ответственные посты в государственном управлении при создании важных государственных учреждений, а также руководя ими (Пранас Довидайтис, Ляонас Бистрас, Юозас Эретас, Мечисловас Рейнис, Эдвардас Тураускас, Стасис Антанас Бачкис и др.). Члены ЛКАН заботились о Литовском государстве в эмиграции (Э. Тураускас, С. А. Бачкис, Ричардас Бачкис, Юозас Бразайтис-Амбразявичюс, Адолфас Дамушис, Витаутас Антанас Дамбрава и др.), участвовали в восстановлении независимого Литовского государства (сигнатары Акта 11 марта), занимали ответственные посты (Витаутас Ландсбергис, Зигмас Зинкявичюс).

Члены ЛКАН - как духовные лица, так и миряне - кроме научной деятельности активно работали и в других областях: в политике, журналистике, в общественной жизни. Они чутко реагировали на актуальные вопросы времени, особое внимание уделяли чести, духовности, истории своего народа, формировали отношение нации к большевизму и нацизму, к образу Литвы и литовцам в эмиграции и т. д.

Члены ЛКАН перевели на литовский язык Библию, в эмиграции выступали в запрещенным советской властью в Литве радиопередачах ("Голос Америки", "Радио Ватикан" и др.). 


\section{Медики в Литовской католической академии наук.}

Научная работа съездов ЛКАН - доклады и дискуссии - проходила в тематических секциях. Здесь началась дальнейшая научная группировка по постоянным предметным секциям.

Медицинские общества в Литве. Для медицинской секции ЛКАН огромное значение имели общества врачей. Первые общества врачей в Литве - это цеха брадобреев (парикмахеров), славившиеся в Великом княжестве Литовском (ВкЛ). А первое медицинское общество, созданное в Вильнюсе в 1805 г., было и первым в Восточной Европе (общество было учреждено по инициативе профессора Вильнюсского Университета Йозефа Франка (1771-1842). Оно заботилось о совершенствовании теоретических знаний и практических навыков врачей и фармацевтов, поднимало незавидное в то время санитарное состояние страны, боролось с заразными болезнями и эпидемиями, вместе с тем оно распространяло просвещение во всей стране, оставив яркий след в истории науки и культуры Литвы. Шотландец Эдуард Дженнер (Eduard Jenner, 1749-1823) - член-корреспондент Вильнюсского Медицинского общества в 1907 г. сделал сообщение об изобретении вакцины против оспы. В Вильнюсе не только начали прививать от оспы, но и в 1908 г. учредили Институт вакцинации - первое научное учреждение такого рода в Европе. Кроме того, Медицинское общество собирало сведения о распространенных в стране болезнях, изучало их причины и способы лечения: была создана лабораторная клиника, а в 1909 г. - первый в Европе Институт материнства, предоставляющий вдовам и небогатым женщинам разностороннюю помощь. В 1908 г. по инициативе Й. Франка в Вильнюсе было создано "Благотворительное общество", проводившее в филантропических целях программу широких социальных мероприятий, боролось с бродяжничеством, заботилось о предоставлениии людям работы, опекало детей, стариков и оставшихся без средств существования людей, обеспечивало уход за больными. В благотворительном обществе действовала и медицинская секция [2].

Созданное в 1885 г. в Каунасе общество стало фундаментом для Каунасского городского Союза врачей (1919), из которого сформировался и вырос Литовский Союз врачей (1924). Во время независимой Литвы медики объединялись по специализациям, о чем свидетельствуют возникшие Литовское Общество хирургов (1935), Литовское Общество детских врачей (1936) и другие общества. В независимой Литве выпускалась также газета "Medicina" ("Медицина", 1920-1940).

Общества медиков в эмиграции. Первая организация, объединявшая литовских медиков в эмиграции, известная уже с 1912 г., называлась "Общество литовских врачей Америки", которое вскоре переросло в "Союз литовских врачей Америки".

Число обществ врачей увеличилось в результате Второй мировой войны, когда угроза советской оккупации заставила многих литовцев по- 
кинуть родину. Так, в 1950 г. было создано Общество литовских врачей Нью-Йорка, в 1956 г. - Общество литовских врачей Охо (вначале объединявшее только медиков Кливленда). Сначала в общество входили только специалисты, получившие медицинское образование в высшем учебном заведении, позже - зубные врачи и ветеринары. Следует подчеркнуть, что это общество создавалось в тот же период, когда в эмиграции восстанавливала свою деятельность Литовская Католическая академия наук.

В Уставе, принятом литовскими врачами Охо, было решено выделять ежегодно по 1000 долларов премии за достижения в области искусства и культуры. Профессионалы-медики всегда были щедрыми и чуткими к нуждам Литвы и литовской эмиграции людьми.

Студенческие организации медиков-атейнинкасов. Говоря о Католической академии, необходимо упомянуть атейнинкасов как звене, которое воспитывалось Академией. Наряду с корпорациями объединявшими студентов-инженеров - "Грандис", девочек - "Гедрос", людей искусства "Шатриёс", в 1928 г. была учреждена корпорация медиков "Гая" (лозунг "В здоровом теле - здоровый дух") [3].

7 ноября 1937 г. филистеры корпорации учредили корпорацию католических врачей "Гая", объединив при этом не только врачей и зубных врачей, но также ветеринаров и фармацевтов. Осенью 1945 г. члены "Гаи" в Тюбингене (Германия) возобновили свою деятельность, а позже успешно ее продолжали в Америке, объединившись с Католической академией.

Важно отметить, что члены Академии широко пропагандировали медицинскую науку. Например, в 1987 г. Всемирный союз литовских врачей издал капитальный труд проф. Юозаса Мяшкаускаса "История медицины в Литве" [4].

Об активном члене ЛКАН, меценате и филантропе, популяризаторе истории и литературы Литвы было немало написано в литовской и эмигрантской печати, в научных изданиях [5], писалось и о деятельности медиков в довоенной Литве и в эмиграции [6].

Секция медицинских наук. Только на втором съезде ЛКАН (1936) была сформирована объединенная секция по медицине и теологии. На ней об уничтожении нерожденной жизни в свете теологической науки говорил иезуит др. Стасис Груодис. В руководство секции были избраны врачи Антанас Старкус (председатель), А. Петраускайте, Ю. Мяшкаускас, Гульбинас и Палёкас. Однако эта секция себя не оправдала, так как уже на третьем съезде она не упоминается.

Постоянной секции медиков не было и во второй период истории Католической академии. Хотя, как уже упоминалось, на созванных в эмиграции съездах ЛКАН было прочитано 22 доклада на медицинские темы (см. схему № 3, стр. 193). 


\section{А. Василяускене}

После возобновления деятельности ЛКАН в Литве секция медиков была создана 25 января 1992 г. Ее председателем был избран проф. Ляонас Мачюнас. Еще до своего объединения в секцию медики проводили значительную работу по распространению приобретенного на Западе опыта в области медицины. Например, 21 декабря 1991 г. проф. Г. Уждавинис поделился впечатлениями о своей поездке во Флориду, рассказал о больнице Св. Винцента. Свой рассказ он иллюстрировал слайдами, выставкой книг и открыток. 1 февраля 1992 г. врач П. Тулявичюс поделился впечатлениями о своей поездке по Таизе (Франция).

На XV съезде в 1991 г. в Вильнюсе (это первый съезд ЛКАН после восстановления в Литве) в 16 секциях было прочитано 72 доклада, в секции медицинских наук - семь (о болезнях легких и сердца, новые способы лечения, применяемых в онкологии, и другие темы).

На состоявшемся в Каунасе XVI съезде Академии (1994) в 13 секциях был прочитан 81 доклад (кроме докладов на пленарных заседаниях). Из них семь докладов в секции медицинских наук, подготовленные 19 учеными.

На XVII съезде, состоявшемся в Вильнюсе в 1997 г., было только семь секций. На них было заслушано 52 доклада. Объединенная секция медиков, на которой было прочитано 11 докладов, называлась "Секция медицины, биологии и сельского хозяйства". Медики говорили о смертности населения Литвы в связи с ухудшением экологического состояния, о распространении инфекционной язвенной болезни, о воздействии табакокурения на органы пищеварительной системы, о радиации и долголетии, о важной общественной проблеме - сне, других темах.

В 2000 г. на организованном в Клайпеде XVIII съезде действовало 15 секций, в программе было запланировано 135 докладов и четыри доклада на пленарном заседании, в медицинской секции - девять. Рассматривались вопросы об особо опасных болезнях и их причины, проблемы абортов, клонирования, эвтаназии и др.

Медики читали доклады и на состоявшемся в 2003 г. в г. Шяуляй XIX съезде ЛКАН, и в 2006 г. на ХХ съезде в Вильнюсе.

Примечательно, что на XIX съезде действовало 19 секций, в которых должны были быть прочитаны 269 докладов и три доклада на пленарных заседаниях. В медицинской секции, объединенной с биохимической, - 30 докладов, но прочитано только 18. Следует подчеркнуть, что хотя докладчиками выступали врачи из разных областей медицины, ни один доклад не был только формальным. Анализировались результаты исследований биологических причин самоубийств, обсуждалась тематика кардиологической рехабилитации, уточнялась связь качества жизни со здоровьем, рассматривались проблемы туберкулеза, обсуждалась тема биохимии витаминов. Председатель медицинской секции ЛКАН д-р Л. Мачюнас (с соавторами) исчерпывающе осветил достоинство и ответственность врача-католика в 
поддержании культуры жизни, а также христианскую этику в медицине. Медицинская секция ЛКАН была представлена как член Европейской федерации врачей-медиков. Работу коллег авторитетно оценил и прокомментировал академик ЛКАН проф. Г. Уждавинис [7].

ХХ съезд (2006), состоявшийся в Вильнюсе, был организован ЛКАН совместно с университетом Миколаса Рёмера. Действовало десять секций, было заслушано 83 доклада в секциях и пять - на пленарных десять заседаниях. Медицинская секция работала два дня, было прочитано десять докладов [8].

Члены ЛКАН - медики не только читали доклады на съездах, семинарах, юбилейных мероприятиях, публиковали статьи в Летописи ЛКАН, но выполняли и другую важную работу.

Замечательная инициатива была предпринята членом ЛКАН - врачом Ауксе Нарвилене, организовавшей в 1997-2001 гг. конференцию знаменитых женщин Церкви. Эти конференции достигли международного уровня. Однако после пяти конференций ученая не только не продолжила эту благородную деятельность, но даже выбыла из Литовской Католической академии наук (ЛКАН) и включилась в другие сферы католической деятельности, одна из которых - борьба за жизнь еще не родившихся младенцев. Деятельность в защиту нерожденных жизней д-р А. Нарвилене начала еще в 1990 г., будучи первым председателем Литовской ассоциации Международной федерации врачей "За жизнь человека". Выйдя из ЛКАН, она посвятила себя проблемам воспитания уважения к человеческой жизни в последний период его жизни. А. Нарвилене активно участвует в Литовском обществе паллиативной медицины, проводит курсы и организует людей для добровольной работы в этой области. В 2007 г. ученая была на четыре года избрана послом Дней культуры при комиссии Союза прибалтийских городов, который объединяет свыше 100 городов, находящихся в десяти странах Балтийского региона (Литву представляют восемь городов).

Медицинская секция ЛКАН, как уже упоминалось, является членом Европейской Федерации врачей-католиков. Ее деятельность в названных сферах способствует популяризации достижений медицины и значительно обогощает Литовскую Католическую академию наук.

\section{Выводы}

1. В деятельности Литовской Католической академии наук можно выделить три периода:

a) 1922-1940 гг. (в Литве);

b) 1956-1992 гг. (в эмиграции, с центром в Риме);

c) С 1990 г. после восстановления ЛКАН в Литве и после возвращения в 1992 г. ее Центрального правления на родину.

2. В структуре ЛКАН большое значение имеет деятельность отделений и секций. 
Литовская Католическая академия наук:

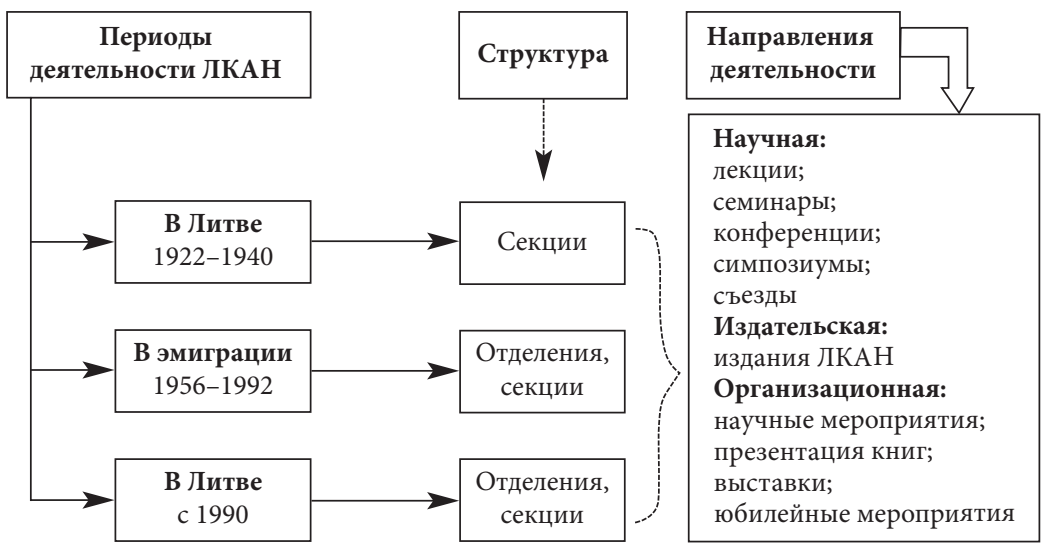

Председатели ЛКАН

Схема № 2

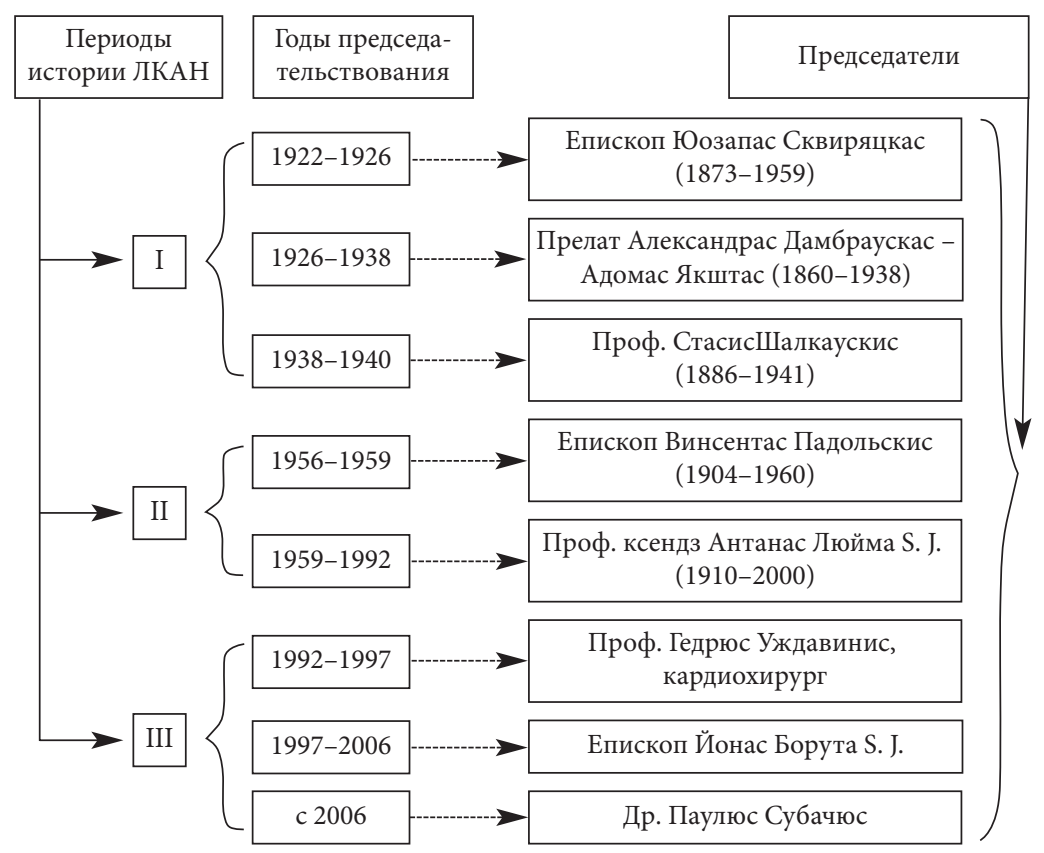


СЕКЦИЯ МЕДИЦИНСКИХ НАУК ЛКАН В ЭМИГРАЦИИ (1956-1990)

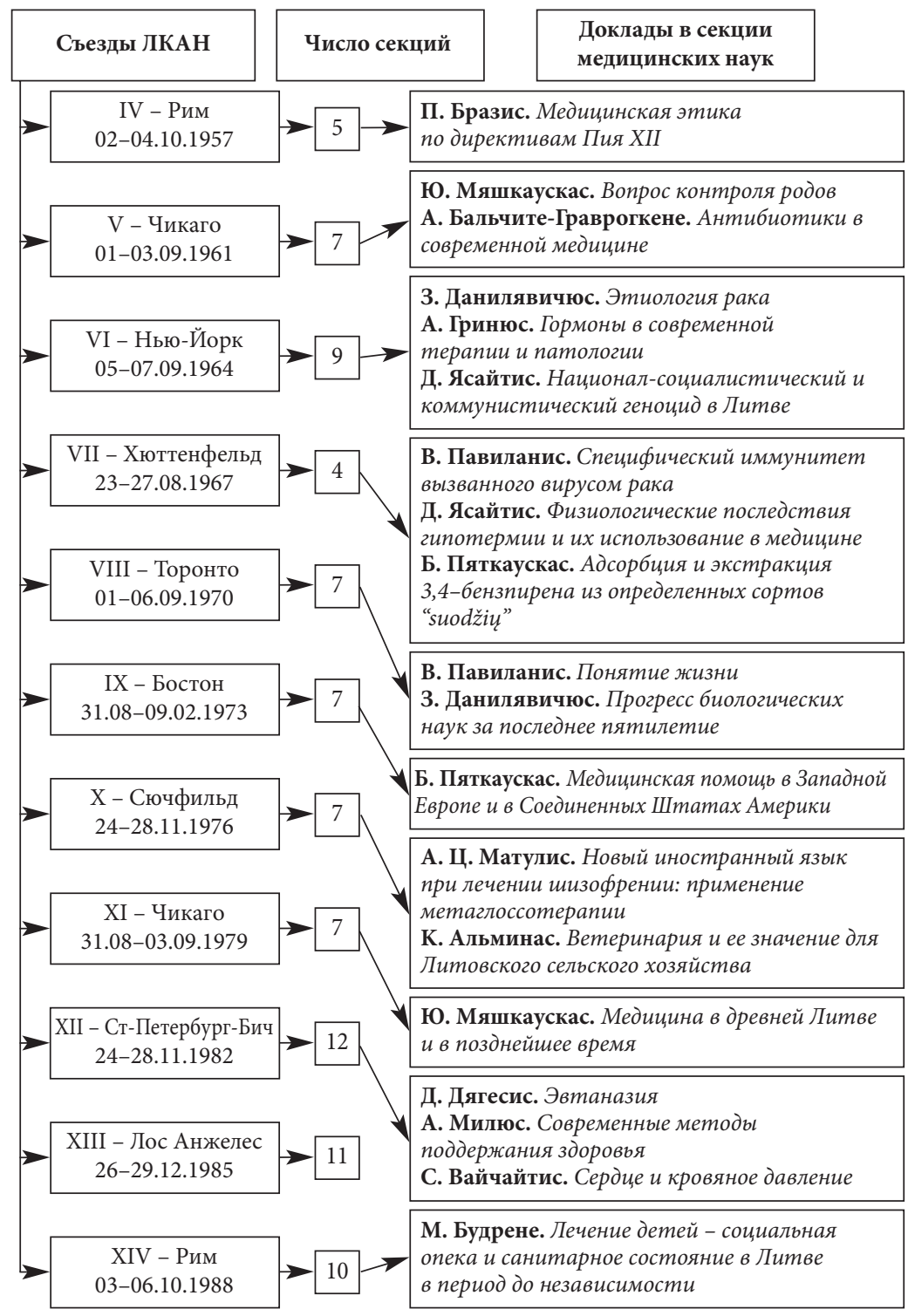


3. Деятельность медиков в Академии имела глубокие исторические корни разные общества медиков.

4. Постоянная медицинская секция ЛКАН не сформировалась ни в первый, ни во второй период истории ЛКАН.

5. После восстановления Академии в Литве члены созданных в Вильнюсе и Каунасе секций медицинских наук выполняют следующую работу:

a) организуют семинары, юбилейные мероприятия;

b) читают доклады на съездах, организуемых ЛКАН и другими организациями;

c) участвуя в научных мероприятиях стран Европы и Америки, представляют и популяризируют Литву, знакомят с ЛКАН;

d) публикуют научные работы в изданиях ЛКАН;

е) поднимают на государственный уровень актуальные проблемы - эвтаназию, аборты, искусственное оплодотворение и др.

6. Медики ЛКАН своей активной деятельностью способствуют распространению в Литве католической мысли, честности и духовности.

\section{Литература}

1. S. Bačkis. LKM Akademijos 60 metų sukakties minëjimas.//LKMA Suvažiavimo darbai. T. 12. Roma: 1987, c. 15-30; M. Bloznelis. Lietuvių katalikų mokslo akademijos raidos kelias.//LKMA Metrašis. T. 22. Vilnius: 2003, c. 133-140; J. Brazaitis. Akademija Tautos kryžkelèse. LKM Akademijai 50 metų sukakties minèjimas.//LKMA Suvažiavimo darbai. T. 9. Roma: 1982, c. 3-17; S. Yla. Lietuviu kataliku mokslo akademija. Bendras žvilgsnis ị praeita kelią. T. 5. Roma: 1964, c. 3-28; R. Krasauskas. Lietuvių katalikų mokslo akademijos veikimo ir darbų apžvalga (1954-1965).//LKMA Metraštis. T. 1. Roma: 1965, c. 329-342; A. Liuima. Lietuvių katalikų mokslo akademijos ištakos ir jos veiklos apžvalga.//LKMA Suvažiavimo darbai. T. 15. Vilnius: 1995, c. 27-41; A. Tyla. Apie LKMA veiklos perspektyvas.//LKMA Metraštis. T. 22. Vilnius: 2003, c. 127-132; A. Tyla. Lietuvių katalikų mokslo akademijai 70 metų sukaktis.//LKMA Metraštis. T. 8. Vilnius: 1994, c. 9-16; A. Vasiliauskiené. Lietuviu kataliku mokslo akademija. Vilnius: 1992. 132 c.; A. Vasiliauskienè. Lietuviu kataliku mokslo akademijos žinynas. Alytus: 1997. 64 c.; A. Vasiliauskiené. LKMA genezès aspektai.//LKMA Metraštis. T. 22. Vilnius: 2003, c. 81-126.

2. G. Zemlickas. Tarnyste mokslui ir gimtajam kraštui. Mokslo Lietuva, №. 3, 2006, Vasario 9-22, c. 5, 7.

3. K. Pemkus. Korp! "Gaja".//Ateitininku keliu. 1911-1927-1977. Žmonés. Ivykiai. Darbai. Red. St. Barzdukas. Chicaga: 1977, c. 132.

4. J. Meškauskas. Lietuvos medicinos istorija. Medicinos mokslas, gyventoju medicininio ir socialinio aprūpinimo istorinè ir dokumentine apžvalga. T. 1. Chicago: Pasaulio lietuvių gydytojų sąjunga. 1987. 814 c. 
5. A. Vasiliauskienè. Albinas Šmulkštys - dvasinių vertybių ieškotojas. Logos, № 51, 2007, c. 216-222; № 52, c. 211-218; A. Vasiliauskienè. Dr. Albinas Šmulkštys: Between spirituality and materiality.//Historiae scientiarum Baltica'06 Vilnius - Kaunas. XXII Baltic Conference on the history of science. T. 2. Vilnius, Kaunas: 2006, c. 120-121; A. Vasiliauskienè. Gydytojo Albino Šmulkščio - studento mediko vilniečio - gyvenimo vingiai.//Vilniaus medicinos istorijos almanachas. T. 2. Red. Aurimas Andriušis. Vilnensis: Medicina, 2006, c. 346-357.

6. A. Vasiliauskienè. Medikų veikla Lietuvių katalikų mokslo akademijoje (19221940).//Mokslo ir technikos raida Lietuvoje. Mokslo istorikų konferencijos, ìvykusios Vilniuje 2004 m. gruodžio 9 d., pranešimai. Vilnius: Technika, 2004, c. 79-84; A. Vasiliauskienè. Lietuvių katalikų mokslo akademija: medikų veikla išeivijoje (1956-1990).//LKMA Metraštis. T. 28. Vilnius: Katalikų akadēmija, 2006, c. 197-213; V. Karvelis, D. A. Šlapkauskaite, V. Zurba. LKMA XIX suvažiavimo, ivvykusios Šiauliuose, kronika.//Suvažiavimo darbai XIX. LKMA Metraščio priedas. III книга. Vilnius: Katalikų akadēmija, 2005, c. 1655-1659.

7. Suvažiavimo darbai XX. LKMA Metraščio priedas. Vilnius: Katalikų akadēmija, 2006, c. 15-26.

\section{The Lithuanian Catholic Academy of Science (Summary)}

\section{By Aldona Vasilauskiene}

The millenium of the first mention of Lithuania's name enables and induces Lithuanian scholars and scientists to produce and spread more knowledge about their country and personalities who took part in the establishment of the state, its institutions and organizations, and made them well-known and strong. The Lithuanian Catholic academy of science (LCAS) is one of those public institutions which are little known to scientists of other countries. It was established in 1922 and performed outstanding work by strengthening the independent state of Lithuania. During the years of Soviet occupation it functioned in exile, advocating Lithuanian's struggle for freedom. The current article reviews the three periods of the LCAS history: in Lithuania (1922-1940); in exile, with its center in Rome (1956-1992); back in Lithuania, when the LCAS was reestablished in 1990 and its General Administration was transferred there in 1992. The article presents the structure of the Academy, its members and its closely interrelated scientific, public and organizational directions of activities. It reviews various associations of medics which used to function as far back as the beginning of the 19th century and at the beginning of the 20th century were established in the diaspora. It is shown 


\section{А. Василяускене}

that the activity of the associations of medics was that substantial base which, years later, made the functioning of the section of medics within the LCAS possible, though, it should be noted, that neither in Lithuania, nor in the diaspora was this section permanent - it was only set up for the period of work of a LCAS conference. A standing section of medical sciences was established at the beginning of 1992 (after the reestablishment of the LCAS in Lithuania). The section organizes seminars, meetings, conferences, moulds the general thematic direction at conventions and produces presenters of papers at them.

The medics, members of the LCAS, through their participation at the academic events of European and American countries, present Lithuania and the LCAS to the world community. The results of the issues under their investigation are manifest in the LCAS publications covering the subject of research and scientific work. It is noteworthy that the members of the LCAS raise to the level of state importance such pressing issues as euthanasia, abortions, artificial impregnation, etc. Their efficient activity contributes to the promotion of Catholic thought, morals and spirituality in Lithuania.

Aldona Vasiliauskienė, doctor of the humanities (history), University of Šiauliai, senior research worker.

LT 02331 Lituania, Vilnius - 06, Vivulskio 15 - 12; tel. 8 (5) 26512 68;

aldona.vasiliauskiene@rstc.vu.lt 